\title{
Effects of Different Treatments on the Quality and Safety of Crayfish (Astacus leptodactylus)
}

\author{
İbrahim Diler, ${ }^{1}$ İsmail Yüksel Genç, ${ }^{2}$ and Abdullah Diler ${ }^{2,3}$ \\ ${ }^{1}$ Aquaculture Department, Fisheries Faculty, Suleyman Demirel University, Isparta, Turkey \\ ${ }^{2}$ Fishing and Processing Technology Department, Fisheries Faculty, Suleyman Demirel University, Isparta, Turkey \\ ${ }^{3}$ Fishing and Processing Technology Department, Fisheries Faculty, İzmir Katip Çelebi University, İzmir, Turkey \\ Correspondence should be addressed to Abdullah Diler; abdullahdiler@sdu.edu.tr
}

Received 31 July 2016; Revised 12 November 2016; Accepted 25 December 2016; Published 14 February 2017

Academic Editor: Jordi Rovira

Copyright (C) 2017 İbrahim Diler et al. This is an open access article distributed under the Creative Commons Attribution License, which permits unrestricted use, distribution, and reproduction in any medium, provided the original work is properly cited.

\begin{abstract}
This study was aimed to determine the effect of different killing methods (frozen, mechanical, and traditional) on the quality, safety, and shelf life of crayfish that are aerobically stored under chilled conditions. The population of microorganisms (i.e., total mesophilic aerobic bacteria (TMAB), total psychrophilic aerobic bacteria (TPAB), and Enterobacteriaceae) was increased regarding to storage time $(p<0.05)$. Significant differences $(p>0.05)$ were not observed in $\mathrm{pH}$ values during storage time. In contrast to this, total volatile basic nitrogen (TVB-N) values of the samples were increased significantly $(p<0.05)$ during storage. Sensory results were highly correlated with the microbiological counts $(r=-0.92$ for TMAB $\times$ odour; $r=-0.95$ for TPAB $\times$ odour; and $r=-0.96$ for Enterobacteriaceae $\times$ odour). Fifteen different fatty acids and 5 biogenic amines were detected for the determination of initial quality and safety of crayfish. In conclusion, frozen killed samples were found to be effective and laborsaving method as an alternative to traditional killing methods by maintaining the quality and safety of crayfish at the beginning and during storage under chilled conditions.
\end{abstract}

\section{Introduction}

The quality of seafood mainly depends on catch/harvest method and processing type. Moreover, changes in microbiological and biochemical values closely related to handling methods after harvesting and play a significant role in maintaining the quality and safety of the product that can be either raw or processed [1]. Crayfish (Astacus leptodactylus) is one of the most preferable crustacean species in terms of its nutritional quality. Turkey has an important place for the processing of crayfish. During 2014 and 2015, the catch yield of the crayfish was reported to be 582 and 532 tons, respectively [2]. Compared to other freshwater crustacean species (i.e., red claw crayfish, Cherax quadricarinatus), A. leptodactylus has one disadvantage in that the tolerance in intensive culture conditions is very low due to cannibalism between individuals. Additionally, A. leptodactylus is sensitive to plague disease that causes remarkable decrease in the population $[3,4]$.

As the rest of seafood, crayfish also could have dramatic changes (i.e., microbiological, chemical, and physical) after harvesting. Due to the differences in nutritional values, spoilage occurs unequally to fish species. Moreover, processing of crayfish is performed while the individuals are still alive to maintain the meat quality [5].

There are limited numbers of studies in the literature regarding the quality and safety of crayfish. Moreover, no available data were found on killing methods as the crayfish are processed alive. In this context, determination of the effect of different treatments (frozen, traditional, and mechanical) on the quality and safety of crayfish was aimed at in the present study.

\section{Materials and Methods}

2.1. Crayfish Samples. Crayfish (A. leptodactylus) samples were obtained from crayfish processing plant when they are alive during the catch season with the total length of $10-14 \mathrm{~cm}$ and weight between 45 and $55 \mathrm{~g}$. The transfer of the crayfish was performed with the drained boxes by a cooling vehicle to the processing plant. Following the processing steps, samples were transferred to the laboratory for the determination of microbiological, sensory, and chemical properties. 
2.2. Killing Methods. Three different killing methods were used in the study, namely, frozen samples (B1), traditional processing (B2), and mechanical methods (B3). Raw crayfish samples were used as control (B4). In all batches 40 crayfish and at the total 160 crayfish were used. For the frozen samples, raw crayfish were placed in the pouches (10 for each) and stored in freezing room $\left(-40^{\circ} \mathrm{C}\right)$ for 3 hours. Traditional killing consisted of immersing the specimens in boiling water for 4 minutes. Specimens were prepared for the mechanical methods by using the tip of sharp scalpel. Individually handled specimens were then immersed in the boiling water after all of the applied killing methods.

2.3. Preparation of Crayfish. The study was divided into 2 batches. In the first batch, samples were analyzed to determine the effect of killing methods on the changes of fatty acids, biogenic amines, and sensory analysis. In the second batch, a shelf life study was conducted to determine whether there is a significant effect on the shelf life of the aerobically stored crayfish during chilled storage $\left(+4^{\circ} \mathrm{C}\right)$. For the determination of the shelf life, samples were examined with regard to the changes in microbiological (TMA, TPA, and Enterobacteriaceae), chemical (TVB-N and $\mathrm{pH}$ ), and sensory properties.

2.4. Microbiological Analysis. Ten grams of crayfish sample from tail was transferred into stomacher pouches containing $90 \mathrm{~mL}$ of $0.1 \%$ Buffered Peptone Water (Merck) and homogenized for 60 seconds. Counts of total mesophilic aerobic (TMA) [6] and total psychrophilic aerobic (TPA) [7] bacteria and Enterobacteriaceae were determined on plate count agar (for TMA and TPA) and Violet Red Bile Glucose Agar (VRBGA), respectively. The incubation period of the bacteria was $30^{\circ} \mathrm{C}$ for 48 hours (TMA), $6^{\circ} \mathrm{C}$ for 240 hours (TPA), and finally $37^{\circ} \mathrm{C}$ for 48 hours (Enterobacteriaceae). Pour plate method was used in duplicate for the counts of microorganisms. Results were expressed as logarithms of the number of colony forming units per gram $(\log \mathrm{cfu} / \mathrm{g})$.

2.5. Sensory Analysis. Sensory analysis of the samples was performed by 9 trained assessors. Four groups (B1 to B4) of crayfish samples were evaluated in accordance with the odour, colour, flavour, texture, and deformation by using 5point Torry scale (1 unacceptable and 5 very good).

2.6. Chemical Analysis. Ten grams of samples was added to $10 \mathrm{~mL}$ of distilled water and homogenized for 2 minutes. The $\mathrm{pH}$ of the samples was directly measured from the diluted homogenate by a $\mathrm{pH}$ meter (Hanna Instruments, UK). Total volatile basic nitrogen (TVBN) (mg N/100 g) was determined in accordance with the method proposed by Antonacopoulos and Vyncke (1989) [8].

2.7. Determination of Fatty Acids. Analysis of fatty acids methyl esters (FAMEs) was performed in accordance with method proposed by AOAC (2001) [9]. Samples were finely homogenized prior to extraction of fat. Following homogenization of $100 \mathrm{mg}$ of pyrogallic acid and $2 \mathrm{~mL}$ of triglyceride internal standard solution, $2 \mathrm{~mL}$ of ethanol and $10 \mathrm{~mL}$ of
$8.3 \mathrm{M}$ of HCI were added and mixed. Samples were maintained into water bath at $70-80^{\circ} \mathrm{C}$ for 40 minutes. In every $10 \mathrm{~min}$, the content of flask was vortexed to incorporate particulates adhering to sides of the flask into solution. After homogenization, the flask was left to cool at room temperature. For the methylation process, extracted fat was dissolved in $2 \mathrm{~mL}$ of chloroform and $2 \mathrm{~mL}$ of diethyl ether. Mixture was transferred into glass vials placed into $40^{\circ} \mathrm{C}$ water bath for the evaporation. Vials were sealed after adding $2 \mathrm{~mL} 7 \%$ of boron trifluoride reagent and $1 \mathrm{~mL}$ of toluene. Vials were heated for $45 \mathrm{~min}$ at $100^{\circ} \mathrm{C}$ and shaken in every 10 minutes. After cooling at room temperature, $5 \mathrm{~mL}$ of $\mathrm{H}_{2} \mathrm{O}, 1.0 \mathrm{~mL}$ of hexane, and $1 \mathrm{~g}$ of $\mathrm{Na}_{2} \mathrm{SO}_{4}$ were added. After separation of layers, the top layer was transferred into another vial containing $1 \mathrm{~g}$ of $\mathrm{Na}_{2} \mathrm{SO}_{4}$. The FAMEs were injected into GC device. A PerkinElmer AutoSystem XL gas chromatography equipped with a capillary column Rt-2560 $(100 \mathrm{~m} \times 0.25 \mathrm{~mm}$ I.D., $0.2 \mu \mathrm{m}$ thickness) was used with the temperature programming from $80^{\circ} \mathrm{C}$ up to $240^{\circ} \mathrm{C}$ (program rate $3^{\circ} \mathrm{C}$ per min.) after keeping split-off mode at $100^{\circ} \mathrm{C}$ for the initial 4-minute hold. The relative amount of each fatty acid methyl ester was calculated from the integrated area of all peaks.

2.8. Analysis of Biogenic Amines in Crayfish Samples. Chemicals used for the analysis of biogenic amines were of analytical and chromatographic grade. Standards, namely, tryptamine, 2-phenylethylamine, putrescine, cadaverine, and tyramine, were obtained from Sigma. Biogenic amine analysis was performed with regard to the method proposed by $[10,11]$.

2.8.1. Apparatus. Shimadzu model HPLC consisting of a LC 10 ADVP pomp, DAD detector $(\lambda \max =220 \mathrm{~nm})$, autosampler (SIL 10 AD VP), and oven (CTO 10 ACVP) was used. The column was Prodigy $5 \mu \mathrm{ODS}(2)(250 \times 4,6 \mathrm{~mm})$ and degasser was DGU-14A.

2.8.2. Chromatographic Conditions. The stock buffer was prepared containing $0.1 \mathrm{M}$ tris-(hydroxymethyl)-aminomethan/ $0.1 \mathrm{M}$ acetic acid/water (MQ): (2/1/2) at $\mathrm{pH}$ 8. Solvent reservoirs consisted of buffer $\mathrm{A}$, buffer $(30 \mathrm{~mL})$, acetonitrile $(\mathrm{ACN}),(550 \mathrm{~mL})$ and water $(420 \mathrm{~mL})$, and buffer $\mathrm{B}$, buffer $(2 \mathrm{~mL}), \mathrm{ACN}(900 \mathrm{~mL})$, and water $(100 \mathrm{~mL})$. The flow rate was $1.0 \mathrm{~mL} / \mathrm{min}$ at $30^{\circ} \mathrm{C}$. Injection volume was $20 \mu \mathrm{L}$.

2.8.3. Sample Preparation. Five grams of sample was homogenized with $0.4 \mathrm{M}$ perchloric acid and centrifuged at $10.000 \mathrm{rpm}$ for $10 \mathrm{~min}$ at $3^{\circ} \mathrm{C}$. Following this, $400 \mu \mathrm{L}$ was taken from supernatant and injected into the column.

2.9. Statistical Analysis. Data were subjected to the analysis of variance (ANOVA) in SPSS ${ }^{\circledR} 16.0$ program for significant differences between treatments. Tukey's multiple test was applied for the comparison of differences between treatments at $p<0.05$ level [12].

\section{Results and Discussion}

3.1. Microbiological Changes. All samples (B1 to B4) were stored at chilled temperature $\left(+4^{\circ} \mathrm{C}\right)$ until the end of the 


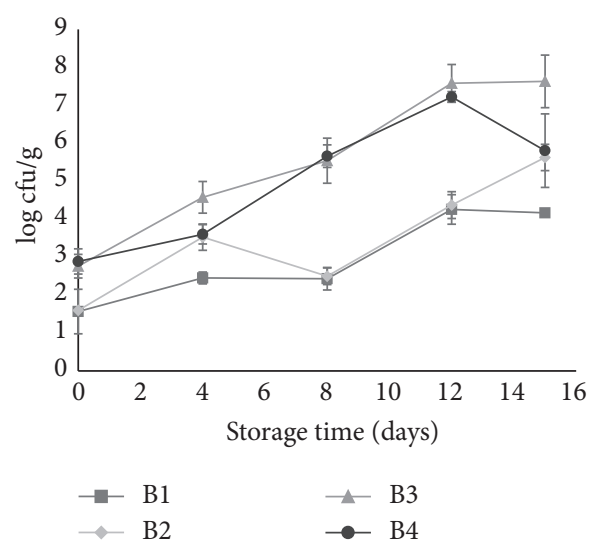

(a)

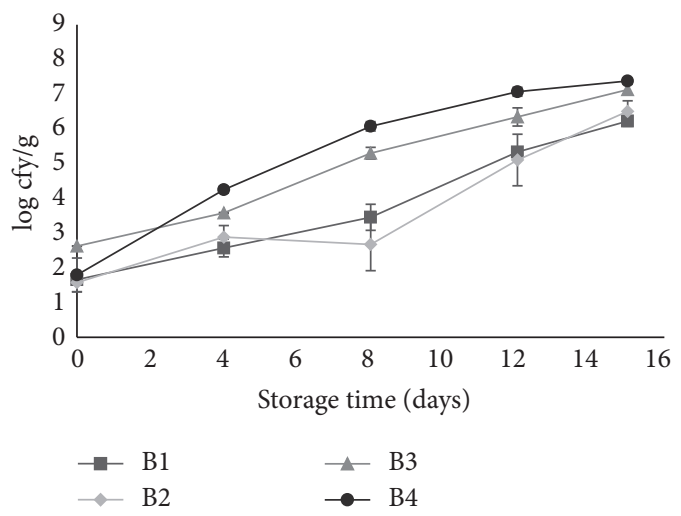

(c)

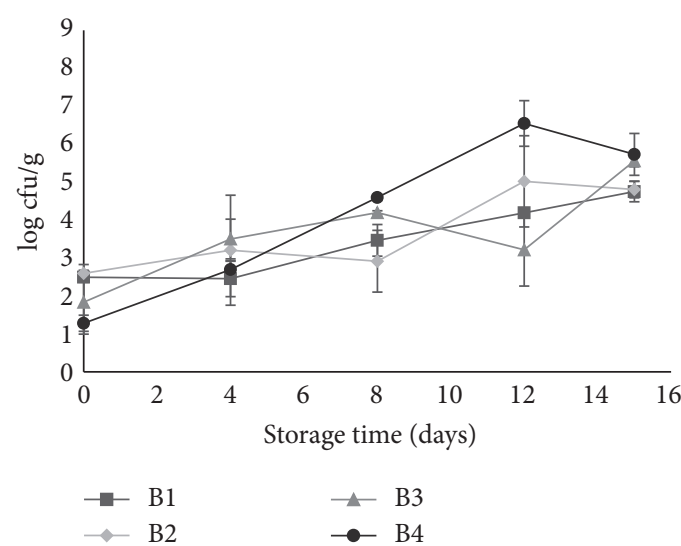

(b)

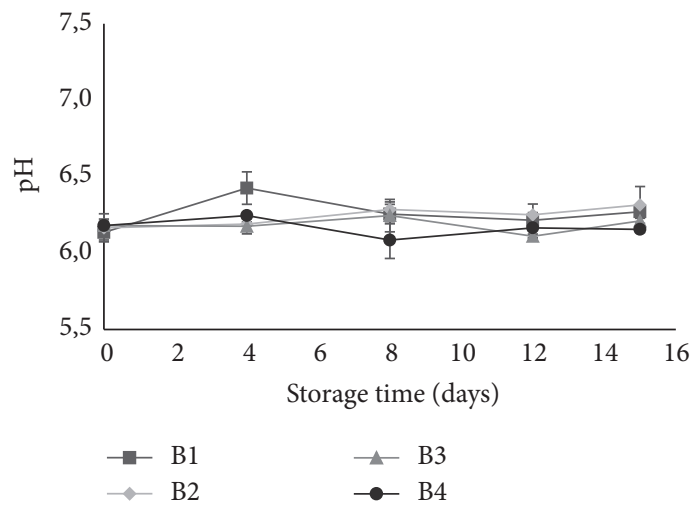

(d)

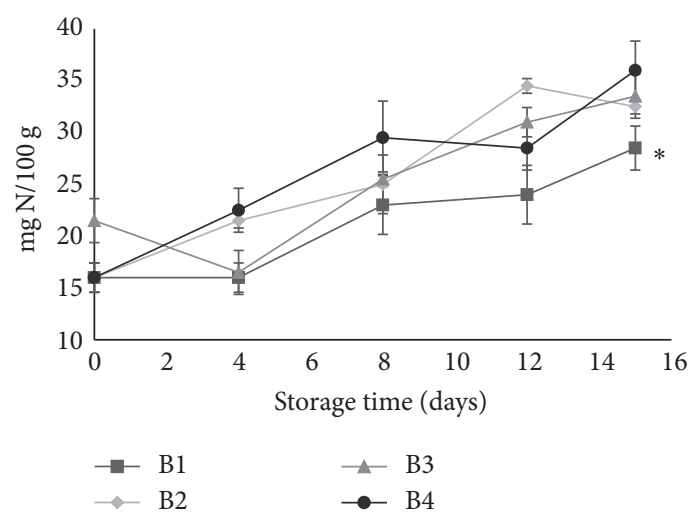

(e)

FIGURE 1: ( $a, b, c)$ Microbiological counts of crayfish samples stored under chilled conditions after application of different killing methods. (a) Total mesophilic aerobic bacteria count, (b) total psychrophilic aerobic bacteria count, and (c) Enterobacteriaceae count. (d, e) Chemical changes of crayfish samples stored under chilled conditions after application of different killing methods; (d) pH and (e) TVBN (mg N/100 g sample). * represents statistically significant $(p<0.05)$ differences among treatments.

shelf life. Initial TMA counts of crayfish samples (B1 to B4) were found to be $1.56 \pm 0.58,1.59 \pm 0.07,2.76 \pm 0.31$, and $2.88 \pm 0.33 \mathrm{log} \mathrm{cfu} / \mathrm{g}$, while TPA and Enterobacteriaceae counts were similar for the initial counts (Figures 1(a), 1(b), and $1(\mathrm{c})$ ). During 15 days of storage time, the counts of microorganisms were increased regardless of the killing method. Due to weak connective tissue, water content, living habitat, and $\mathrm{pH}$ values, the growth of bacteria was induced during storage [13-15].

The initial counts of TPA bacteria were found to be $2.49 \pm$ $0.06,2.59 \pm 0.23,1.83 \pm 0.84$, and $1.28 \pm 0.21 \mathrm{log} \mathrm{cfu} / \mathrm{g}$ after application of killing methods. During storage at chilled temperatures, the counts of bacteria were significantly increased $(p<0.05)$. The highest counts $(5.73 \pm 0.55 \log \mathrm{cfu} / \mathrm{g})$ were 
TABLE 1: Sensory changes of crayfish samples stored under chilled conditions after application of different killing methods (mean \pm standard deviation).

\begin{tabular}{|c|c|c|c|c|c|c|}
\hline Group & Storage time (days) & Odour & Deformation & Colour & Texture & Flavour \\
\hline \multirow{5}{*}{ B1 } & 0 & $4.55 \pm 0.52^{\mathrm{a}}$ & $4.00 \pm 0.50^{\mathrm{b}}$ & $4.55 \pm 0.52^{\mathrm{bc}}$ & $3.77 \pm 0.83^{b}$ & $4.00 \pm 0.70^{\mathrm{ab}}$ \\
\hline & 4 & $3.88 \pm 0.60$ & $4.00 \pm 0.70$ & $3.55 \pm 0.52$ & $4.00 \pm 0.86$ & $4.00 \pm 0.70$ \\
\hline & 8 & $3.00 \pm 0.75$ & $3.12 \pm 0.64$ & $3.00 \pm 0.53$ & $3.00 \pm 0.75$ & $3.25 \pm 0.46$ \\
\hline & 12 & $2.33 \pm 0.50$ & $2.22 \pm 0.44$ & $2.55 \pm 0.52$ & $2.22 \pm 0.44$ & $2.66 \pm 0.50$ \\
\hline & 15 & $2.22 \pm 0.44$ & $2.55 \pm 0.52$ & $2.33 \pm 0.50$ & $1.65 \pm 0.49$ & $2.44 \pm 0.52$ \\
\hline \multirow{5}{*}{ B2 } & 0 & $4.44 \pm 0.52^{\mathrm{b}}$ & $4.33 \pm 0.70^{\mathrm{a}}$ & $4.44 \pm 0.52^{\mathrm{d}}$ & $4.33 \pm 0.50^{b}$ & $4.44 \pm 0.52^{b}$ \\
\hline & 4 & $3.77 \pm 0.44$ & $3.33 \pm 0.50$ & $3.88 \pm 0.60$ & $4.44 \pm 0.52$ & $4.33 \pm 0.50$ \\
\hline & 8 & $3.33 \pm 0.50$ & $2.55 \pm 0.72$ & $4.00 \pm 0.70$ & $2.77 \pm 0.66$ & $3.44 \pm 0.52$ \\
\hline & 12 & $1.33 \pm 0.50$ & $1.44 \pm 0.52$ & $2.88 \pm 0.78$ & $2.00 \pm 0.70$ & $3.11 \pm 0.60$ \\
\hline & 15 & $1.33 \pm 0.50$ & $1.22 \pm 0.44$ & $2.22 \pm 0.66$ & $1.44 \pm 0.52$ & $2.22 \pm 0.66$ \\
\hline \multirow{5}{*}{ B3 } & 0 & $3.55 \pm 0.72^{\mathrm{b}}$ & $3.55 \pm 0.52^{\mathrm{ab}}$ & $3.77 \pm 0.66^{\mathrm{b}}$ & $4.44 \pm 0.52^{\mathrm{b}}$ & $4.44 \pm 0.52^{\mathrm{a}}$ \\
\hline & 4 & $2.88 \pm 0.60$ & $3.44 \pm 0.52$ & $4.11 \pm 0.60$ & $4.44 \pm 0.52$ & $4.33 \pm 0.50$ \\
\hline & 8 & $3.11 \pm 0.60$ & $3.00 \pm 1.00$ & $3.22 \pm 0.44$ & $3.22 \pm 0.66$ & $3.44 \pm 0.52$ \\
\hline & 12 & $2.55 \pm 0.52$ & $2.88 \pm 0.78$ & $2.66 \pm 0.50$ & $2.66 \pm 0.50$ & $2.66 \pm 0.70$ \\
\hline & 15 & $1.44 \pm 0.52$ & $1.33 \pm 0.50$ & $1.44 \pm 0.52$ & $1.44 \pm 0.52$ & $1.22 \pm 0.44$ \\
\hline \multirow{5}{*}{ B4 } & 0 & $4.22 \pm 0.66^{\mathrm{b}}$ & $4.00 \pm 0.70^{\mathrm{ab}}$ & $4.00 \pm 0.70^{\mathrm{a}}$ & $3.00 \pm 0.70^{\mathrm{a}}$ & NP \\
\hline & 4 & $3.55 \pm 0.52$ & $3.88 \pm 0.60$ & $3.44 \pm 0.52$ & $2.88 \pm 0.60$ & NP \\
\hline & 8 & $2.66 \pm 0.50$ & $3.55 \pm 0.52$ & $2.00 \pm 0.70$ & $2.00 \pm 0.70$ & NP \\
\hline & 12 & $2.33 \pm 0.86$ & $1.77 \pm 0.66$ & $1.11 \pm 0.33$ & $1.44 \pm 0.52$ & NP \\
\hline & 15 & $1.11 \pm 0.33$ & $1.22 \pm 0.44$ & $1.22 \pm 0.44$ & $1.22 \pm 0.44$ & NP \\
\hline
\end{tabular}

Different superscripts on the same column represent significant differences between treatments $(p<0.05)$. NP means that analyses were not performed.

obtained for the fresh raw samples (B4) at the end of the storage time.

The members of Enterobacteriaceae family play a significant role in spoilage pattern of seafood [16]. In this study, the lowest initial counts of Enterobacteriaceae were observed in traditionally killed samples $(1.57 \pm 0.26 \log \mathrm{cfu} / \mathrm{g})$, while mechanically killed samples had the highest count which was $2.62 \pm 0.007 \log \mathrm{cfu} / \mathrm{g}$. At the end of the storage time, significant results were observed between B1 and B4 ( $p<$ $0.05)$. Among the treatments, the lowest microbial counts were found in frozen killed (B1) samples at the end of the storage time. Similar results were obtained compared to a study that was conducted to investigate the microbiological and physicochemical properties of red claw crayfish $(C$. quadricarinatus) at chilled temperatures $\left(2^{\circ} \mathrm{C}\right)$ [17]. It has been reported that at the beginning of the storage trial the microbiota of red claw crayfish have been affected by the slurry ice and lower results were obtained for aerobic plate count $(2 \log \mathrm{cfu} / \mathrm{g})$ and coliform bacteria. Regarding our study, the counts of all of the bacterial groups were inhibited due to freezing temperature $\left(-40^{\circ} \mathrm{C}\right)$.

3.2. Chemical Changes. Changes in $\mathrm{pH}$ and TVBN ( $\mathrm{mg} \mathrm{N} /$ $100 \mathrm{~g})$ values were presented in Figures 1(d) and 1(e). The differences among the initial $\mathrm{pH}$ of the samples were not significant $(p>0.05)$. During storage, $\mathrm{pH}$ values exhibited fluctuated changes. Although statistically significant differences among the treatments were not found during storage, the differences compared to the first day of the storage were significant $(p<0.05)$. The lowest $\mathrm{pH}$ was found in fresh raw samples $(6.14 \pm 0.02)$. Similar results were obtained in the study conducted by [18] Fard et al. (2015), in which tail meat quality changes of $A$. leptodactylus were studied.

The mean results of TVBN values of crayfish samples were found to be $28.5 \pm 2.12,32.5 \pm 0.7,33.5 \pm 2.12$, and $36.0 \pm$ $2.82 \mathrm{mg} \mathrm{N} / 100 \mathrm{~g}$ sample at the end of the storage trial, respectively (Figure 1(e)). Significant differences $(p<0.05)$ were only observed in frozen killed samples compared to other killing methods. Higher results $(53.5 \pm 1.204 \mathrm{mg} \mathrm{N} / 100 \mathrm{~g})$ were reported by [19] for freshwater crayfish (Procambarus clarkii). On the other hand, obtained TVBN results were consistent with the findings of Fard et al. (2015) [18] for frozen A. leptodactylus tail fillets. Researchers reported the maximum reached TVBN values of crayfish tail fillet as $26.6 \pm 1.4 \mathrm{mg} \mathrm{N} / 100 \mathrm{~g}$ sample at the end of 6-month storage. The allowance limit of TVBN content in seafood has been reported to be less than $40 \mathrm{mg} \mathrm{N} / 100 \mathrm{~g}$ sample [20, 21]. However, the acceptable limit for TVBN values highly depends on the species. Regarding this study, TVB-N values did not reach the acceptable limit ( $40 \mathrm{mg} \mathrm{N} / 100 \mathrm{~g}$ sample) at the end of the storage time. However, samples were rejected by sensory panel after 15 days.

3.3. Sensory Changes. Sensory changes of crayfish were shown in Table 1. The samples were judged in accordance with their odour (characteristic, fishy, neutral, rancid, and boiled egg), deformation (unusual appearance on carapace), colour (white, yellow/greenish, or paled), texture (hardness 
TABLE 2: Fatty acids profile of crayfish samples after application of different killing methods.

\begin{tabular}{|c|c|c|c|c|c|c|c|}
\hline & atty acids (\%) & B1 & B2 & B3 & B4 & Sum & Mean \pm SD \\
\hline $\mathrm{C} 14: 0$ & Myristic acid & 1.12 & 10.63 & 3.35 & 0.86 & 15.96 & $3.99 \pm 4.56$ \\
\hline $\mathrm{C} 16: 0$ & Palmitic acid & 17.55 & 34.56 & 20.67 & 16.01 & 88.79 & $22.19 \pm 8.46$ \\
\hline C16:1 & Palmitoleic acid & 5.53 & 2.30 & 3.91 & 5.63 & 17.37 & $4.34 \pm 1.57$ \\
\hline $\mathrm{C} 17: 0$ & Heptadecanoic acid & 1.10 & 1.28 & 1.06 & 1.03 & 4.47 & $1.11 \pm 0.11$ \\
\hline $\mathrm{C} 17: 1$ & c-10 Heptadecanoic acid & 0.81 & ND & ND & 1.17 & 1.98 & $0.49 \pm 0.59$ \\
\hline C18:0 & Stearic acid & 8.83 & 17.17 & 11.35 & 6.98 & 44.33 & $11.08 \pm 4.43$ \\
\hline $\mathrm{C} 18: \ln 9$ & Elaidic acid & 15.02 & 14.08 & 14.58 & 13.44 & 57.12 & $14.28 \pm 0.67$ \\
\hline $\mathrm{C} 18: \ln 9$ & Oleic acid & 5.40 & 1.72 & 4.37 & 4.07 & 15.56 & $3.89 \pm 1.55$ \\
\hline $\mathrm{C} 18: 2 \mathrm{n} 6$ & Linoleic acid & 5.54 & 3.50 & 4.57 & 6.56 & 20.17 & $5.04 \pm 1.31$ \\
\hline C20:1 & c-11 Eicosenoic acid & 4.36 & 1.25 & 3.28 & 2.02 & 10.91 & $2.72 \pm 1.37$ \\
\hline $\mathrm{C} 20: 2$ & c-11 14-Eicosadienoic acid & 1.31 & ND & 0.98 & 1.99 & 4.28 & $1.07 \pm 0.82$ \\
\hline $\mathrm{C} 22: \ln 9$ & Erucic acid & 8.46 & 2.15 & 6.60 & 11.85 & 29.06 & $7.26 \pm 4.04$ \\
\hline C24:0 & Lignoceric acid & 18.06 & 6.11 & 16.91 & 16.27 & 57.35 & $14.33 \pm 5.53$ \\
\hline C24:1 & Nervonic acid & ND & ND & ND & 0.7 & 0.7 & - \\
\hline $\mathrm{C} 22: 6 \mathrm{n} 3$ & Docosahexaenoic acid & ND & 1.16 & 3.79 & 3.92 & 8.87 & $2.95 \pm 1.53$ \\
\hline
\end{tabular}

$\mathrm{ND}$, not detected.

and juiciness), and flavour (characteristic, rancid, and sulphur) during the storage time. Results were scaled from 1 (unacceptable) to 5 (perfect quality). During the 15 days of storage trial significant differences were found between treatments $(p<0.05)$. The effect of time was found to be statistically significant within the groups $(p<0.05)$. Odour is one of the most explicit changes among the parameters of the sensory analysis. With regard to the storage time, values were decreased significantly $(p<0.05)$ for all treatments tested. The lowest results were obtained for fresh raw samples (B4), while the highest ones were for frozen killed crayfish (B1) (Table 1).

Detection of deformation level among the samples was obvious in mechanically killed crayfish (B3). Although the lowest deformation was observed in fresh raw and traditionally killed samples, initial values of deformation between B3 and B4 were not statistically significant $(p>0.05)$. The values of colour changes were decreased with regard to storage time. Initial colour values which represent white tail meat and reddish shell for killed and boiled samples and greenish tail meat and green shell for fresh raw samples were found to be $3.77 \pm 0.83,4.33 \pm 0.50,4.44 \pm 0.52$, and $4.00 \pm 0.70$, respectively. During the storage time, colour of the processed samples (B1 to B3) was changed from the white tail meat to greenish/yellowish and from red to pale for the shell. The initial texture values of the samples were found to be $3.77 \pm$ $0.83,4.33 \pm 0.50,4.44 \pm 0.52$, and $3.00 \pm 0.70$, respectively. The lowest texture value belonged to group B4 $(1.22 \pm 0.44)$ which could be due to highest microbial and enzymatic activity (Figures 1(a), 1(b), and 1(c)) during storage. Changes in flavour which represent overall acceptability for the boiled samples decreased as well with regard to storage time. Flavour analysis was not applied for group B4 as they were stored fresh raw samples. At the end of the storage trial, the highest flavour results were obtained in group B1 $(p<0.05)$. Similar results were reported by Sigurgisladottir et al. (2001) [22] for the texture changes of fresh and smoked Atlantic salmon (Salmo salar). Moreover, the significant effects of killing/processing methods on the sensory changes of crayfish have been shown in this study. Consistent findings were also reported in the previous study [23].

3.4. Fatty Acid and Biogenic Amine Profile of Crayfish. The fatty acid profile of crayfish samples was presented in Table 2. The domination of fatty acids of fresh raw crayfish consisted of saturated (palmitic acid (C16:0) (16.01\%), stearic acid $(\mathrm{C} 18: 0)(6.98 \%))$ and monounsaturated (elaidic (C18:1n9) (13.44\%), erucic (C22:1n9) (11.85\%), and lignoceric acid (C24:0) (16.27\%)). With regard to the killing method tested herein, variations in the percentage of fatty acids were observed. Compared to the control group (B4), loss of fatty acids due to killing methods was not found to be statistically significant $(p>0.05)$. One of the most significant differences was found between groups in erucic acid (C22:1n9) which could cause myocardial lipidosis in animals [24]. Lower results were reported compared to our study for erucic acid in muscle tissue of cultured and wild rohu (Labeo rohita) [25]. Higher amounts of erucic acid were observed in the crayfish which may be due to high absorption of erucic acid in the muscle tissue.

The profile of biogenic amines content was shown in Table 3. The dominated biogenic amines were found to be tryptamine, putrescine, and cadaverine in crayfish samples. Tyramine and 2-phenylethylamine were only found in group B2 with very low amount of $0.3 \mu \mathrm{g} / \mathrm{g}$. Tryptamine, putrescine, and cadaverine are found in seafood and reported in many studies [26-29].

\section{Conclusion}

The effect of different killing methods on the quality and safety of crayfish was investigated in the study. In terms of 
TABLE 3: Biogenic amines profile of crayfish samples after application of different killing methods.

\begin{tabular}{|c|c|c|c|c|c|}
\hline Groups & Tryptamine & 2-Phenylethylamine & Putrescine & Cadaverine & Tyramine \\
\hline $\mathrm{B} 1$ & 3.0 & ND & 2.9 & 0.8 & ND \\
\hline B2 & 1.3 & 0.3 & 0.9 & 0.5 & 0.3 \\
\hline B3 & 2.4 & ND & 1.7 & 0.6 & ND \\
\hline B4 & 2.5 & ND & 4.9 & 0.8 & ND \\
\hline Sum & 9.20 & 0.3 & 10.40 & 2.70 & 0.3 \\
\hline Mean \pm SD & $2.30 \pm 0.71$ & - & $2.60 \pm 1.73$ & $0.67 \pm 0.15$ & - \\
\hline
\end{tabular}

$\mathrm{ND}$, not detected.

determining the quality of crayfish samples, microbiological changes, sensory indices, and fatty acid profile were taken into account, while biogenic amines content was quantified for the evaluation of safety of the samples. Moreover, a study on 15 days of shelf life was also conducted to determine the significant effect of different killing methods in crayfish under chilled conditions. Obviously, the highest microbial activity and chemical changes (TVB-N) were observed in fresh raw crayfish samples (B4). By taking into account the traditional processing method in which crayfish are killed while they are still alive, the most effective method was found to be frozen killed crayfish. Freezing has positive effects on maintaining the quality and safety of crayfish samples when they are stored aerobically under chilled conditions. As a result of this study, it could be recommended that frozen killing could be an alternative, laborsaving, and effective method in the field of crayfish processing industry.

\section{Competing Interests}

The authors declare that there are no competing interests regarding the publication of this paper.

\section{Acknowledgments}

The authors thank Şahlanlar Food Industry and Trade Inc. for providing the crayfish samples.

\section{References}

[1] A. D. Bonnell, Quality Assurance in Seafood Processing: A Practical Guide, Springer US, Boston, Mass, USA, 1994.

[2] Turkish Statistical Institute, 2016, http://www.tuik.gov.tr/PreTablo.do?alt_id=1005.

[3] J. Svoboda, E. Kozubíková, P. Kozák et al., "PCR detection of the crayfish plague pathogen in narrow-clawed crayfish inhabiting Lake Eğirdir in Turkey," Diseases of Aquatic Organisms, vol. 98, no. 3, pp. 255-259, 2012.

[4] M. M. Harlioğlu, "The harvest of the freshwater crayfish Astacus leptodactylus Eschscholtz in Turkey: harvest history, impact of crayfish plague, and present distribution of harvested populations," Aquaculture International, vol. 16, no. 4, pp. 351360, 2008.

[5] G. CyIll, H. L. Gallant, and R. Ablett, "Methods for recovering raw meat from the head-shells of crustaceans; e.g. lobster and use thereof for stuffed crustaceans, e.g. lobster and stuffing soprovided," United states patent, Patent No: US 6,235,338 B1, 2001.

[6] ISO, ISO 4833 Microbiology of Food and Animal Feeding StuffsHorizontal Method for the Enumeration of MicroorganismsColony-Count Technique at $30^{\circ} \mathrm{C}$, International Organization for Standardization, Genève, Switzerland, 2003.

[7] ISO, ISO 17410 Microbiology of Food and Animal Feeding Stuffs-Horizontal Method for the Enumeration of Psychrotrophic Microorganisms, International Organization for Standardization, Geneva, Switzerland, 2001.

[8] N. Antonacopoulos and W. Vyncke, "Determination of volatile basic nitrogen in fish: a third collaborative study by the West European Fish Technologists' Association (WEFTA)," Zeitschrift für Lebensmittel-Untersuchung und -Forschung, vol. 189, no. 4, pp. 309-316, 1989.

[9] AOAC, "AOAC official method 996.06, Fat (total, saturated and unsaturated) in foods hydrolytic extraction gas chromatographic method," 2001.

[10] Z. Öner, A. Gül Karahan, and H. Aloğlu, "Changes in the microbiological and chemical characteristics of an artisanal Turkish white cheese during ripening," $L W T$-Food Science and Technology, vol. 39, no. 5, pp. 449-454, 2006.

[11] R. E. Anl, N. Vural, S. Yilmaz, and Y. H. Vural, "The determination of biogenic amines in Turkish red wines," Journal of Food Composition and Analysis, vol. 17, no. 1, pp. 53-62, 2004.

[12] E. Esteves, "Statistical analysis in food science," in Practical Food and Research, R. M. Cruz, Ed., pp. 409-451, Nova Science Publishers Inc, Hauppauge, NY, USA, 2011.

[13] M. Sautour, P. Mary, N. E. Chihib, and J. P. Hornez, "The effects of temperature, water activity and $\mathrm{pH}$ on the growth of Aeromonas hydrophila and on its subsequent survival in microcosm water," Journal of Applied Microbiology, vol. 95, no. 4, pp. 807-813, 2003.

[14] K. P. Koutsoumanis, P. A. Kendall, and J. N. Sofos, "Modeling the boundaries of growth of Salmonella typhimurium in broth as a function of temperature, water activity, and $\mathrm{pH}$," Journal of Food Protection, vol. 67, no. 1, pp. 53-59, 2004.

[15] O. Mejlholm and P. Dalgaard, "Modeling and predicting the growth boundary of Listeria monocytogenes in lightly preserved seafood," Journal of Food Protection, vol. 72, no. 10, pp. 21322143, 2007.

[16] L. Gram and P. Dalgaard, "Fish spoilage bacteria-problems and solutions," Current Opinion in Biotechnology, vol. 13, no. 3, pp. 262-266, 2002. 
[17] G. Chen, Y. L. Xiong, B. Kong et al., "Microbiological and physicochemical properties of red claw crayfish (Cherax quadricarinatus) stored in different package systems at $2 \circ \mathrm{C}$," Journal of Food Science, vol. 72, no. 8, pp. E442-E449, 2007.

[18] A. N. Fard, M. Seidgar, and D. Azadikhah, "The study of frozen Astacus leptodactylus tail fillet quality changes," AACL Bioflux, vol. 8, no. 6, pp. 988-998, 2015.

[19] N. F. Zaglol and F. Eltadawy, "Study on chemical quality and nutrition value of fresh water crayfish (Procambarus clarkii)," Journal of the Arabian Aquaculture Society, vol. 4, no. 1, pp. 1$18,2009$.

[20] H. H. Huss, Fresh Fish-Quality and Quality Changes, FAO Fisheries Series no. 29, FAO, Rome, Italy, 1988.

[21] H. H. Huss, "Assurance of seafood quality," FAO Fisheries Technical Paper, FAO, Rome, Italy, 1994.

[22] S. Sigurgisladottir, M. S. Sigurdardottir, H. Ingvarsdottir, O. J. Tprrisssen, and H. Hafsteinsson, "Microstructure and texture of fresh and smoked Atlantic salmon, Salmo salar L., fillets from fish reared and slaughtered under different conditions," Aquaculture Research, vol. 32, no. 1, pp. 1-10, 2001.

[23] S. Sigurgisladottir, H. Ingvarsdottir, O. J. Torrissen, M. Cardinal, and H. Hafsteinsson, "Effects of freezing/thawing on the microstructure and the texture of smoked atlantic salmon (Salmo salar)," Food Research International, vol. 33, no. 10, pp. 857-865, 2000.

[24] Food Standards Australia New Zealand, "Erucic acid in food: a toxicological review and risk assessment," Technical Report Series no. 21, Food Standards Australia New Zealand, Canberra, Australia, 2003.

[25] P. Sharma, V. Kumar, A. K. Sinha, J. Ranjan, H. M. P. Kithsiri, and G. Venkateshwarlu, "Comparative fatty acid profiles of wild and farmed tropical freshwater fish rohu (Labeo rohita)," Fish Physiology and Biochemistry, vol. 36, no. 3, pp. 411-417, 2010.

[26] V. Šimat and P. Dalgaard, "Use of small diameter column particles to enhance HPLC determination of histamine and other biogenic amines in seafood," LWT-Food Science and Technology, vol. 44, no. 2, pp. 399-406, 2011.

[27] R. Draisci, G. Volpe, L. Lucentini, A. Cecilia, R. Federico, and G. Palleschi, "Determination of biogenic amines with an electrochemical biosensor and its application to salted anchovies," Food Chemistry, vol. 62, no. 2, pp. 225-232, 1998.

[28] H.-C. Chen, Y.-R. Huang, H.-H. Hsu et al., "Determination of histamine and biogenic amines in fish cubes (Tetrapturus angustirostris) implicated in a food-borne poisoning," Food Control, vol. 21, no. 1, pp. 13-18, 2010.

[29] F. Özogul, K. D. A. Taylor, P. Quantick, and Y. Özogul, "Biogenic amines formation in Atlantic herring (Clupea harengus) stored under modified atmosphere packaging using a rapid HPLC method," International Journal of Food Science and Technology, vol. 37, no. 5, pp. 515-522, 2002. 

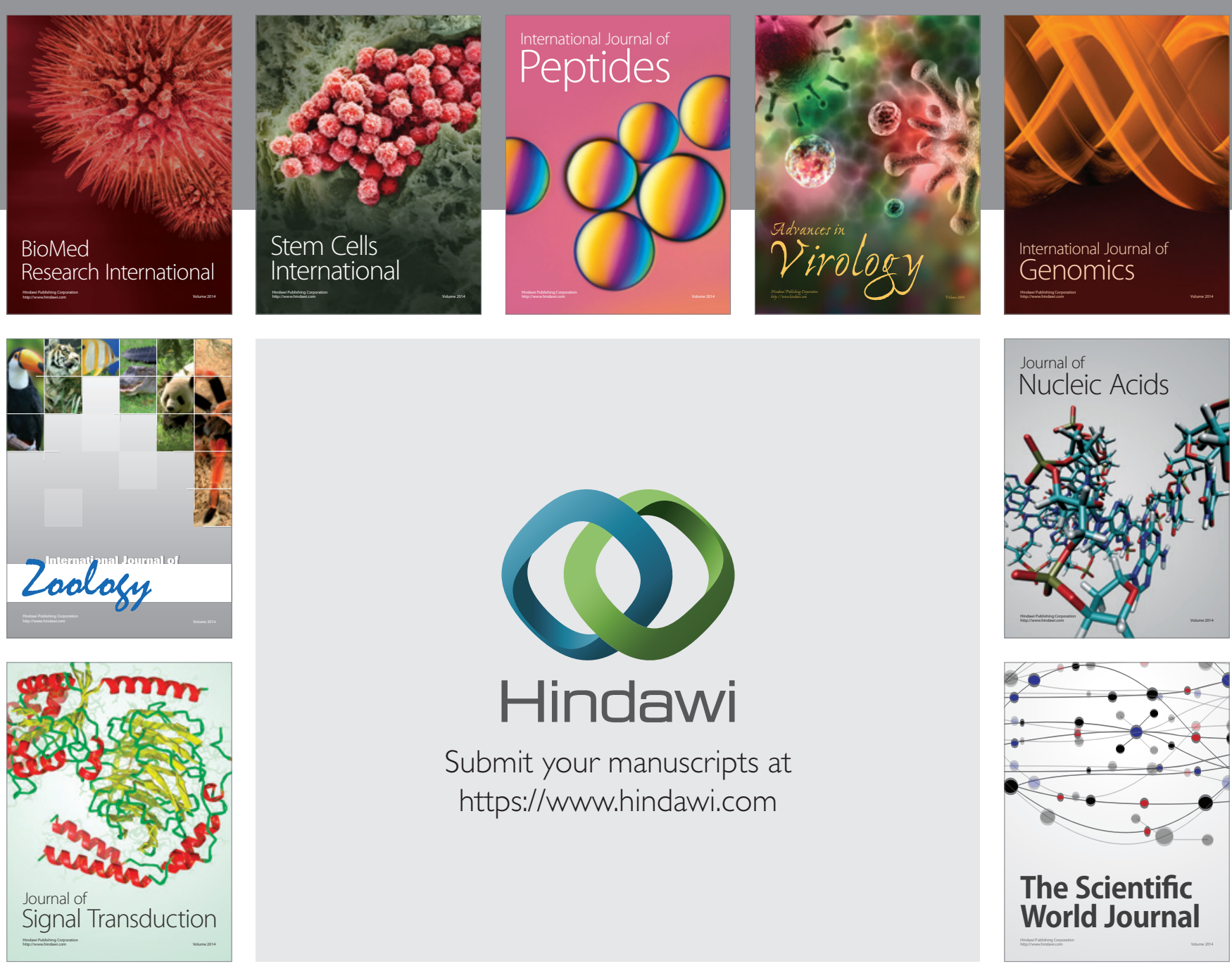

Submit your manuscripts at

https://www.hindawi.com
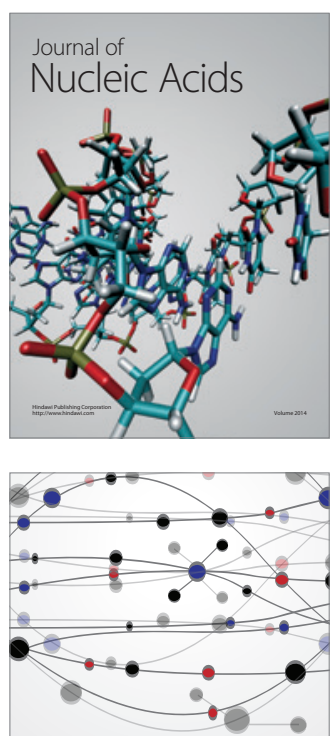

The Scientific World Journal
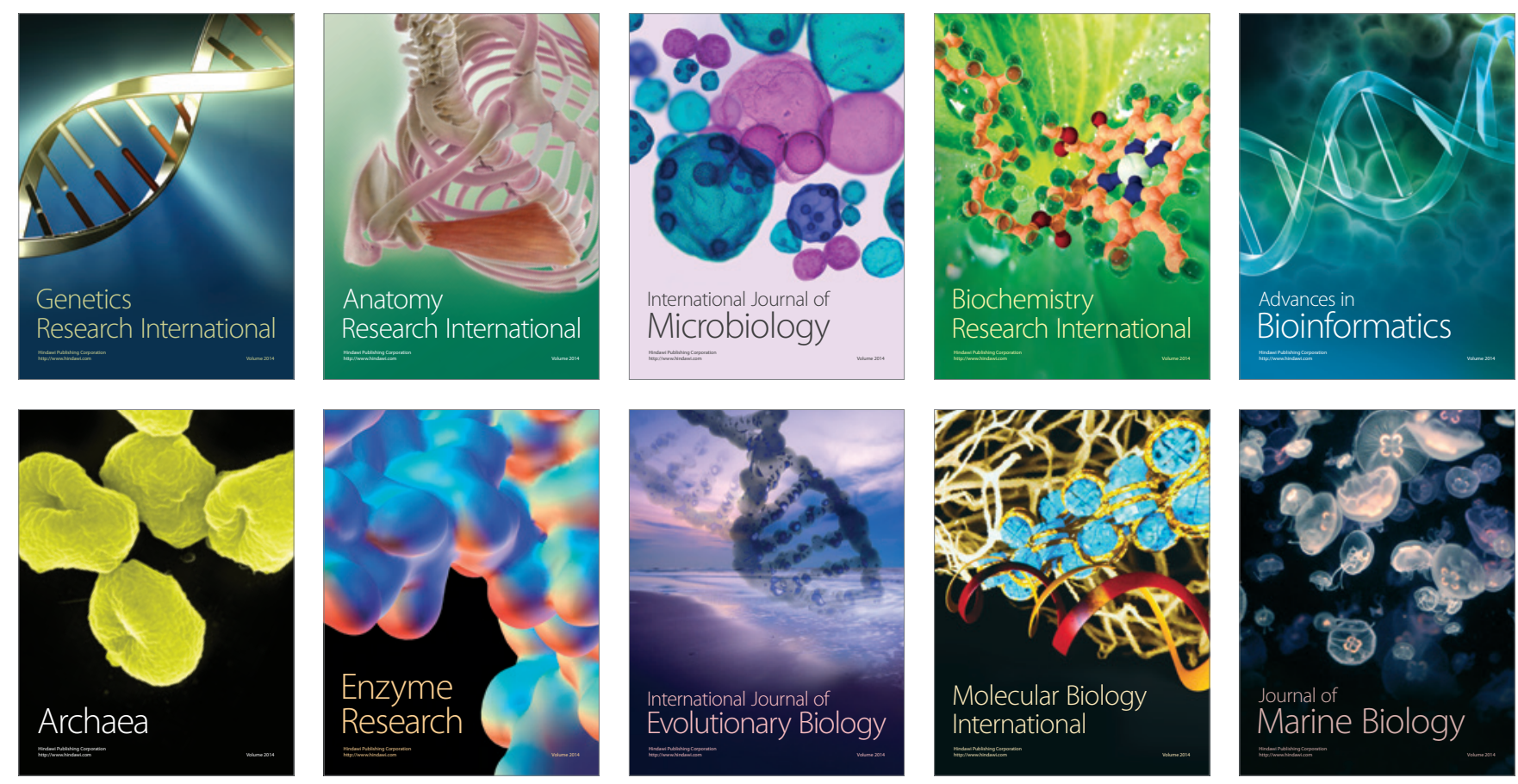